\title{
Digital Transformation of the Government: A Case Study in Indonesia
}

\author{
SITTI AMINAH \\ HERIE SAKSONO \\ Research and Development Agency, Ministry of Home Affairs, Indonesia
}

\begin{abstract}
The world's Industrial Revolution 4.0 and Society 5.0 are massively utilising the Internet of Things, Big Data, Artificial Intelligence and Robotic technology to solve various challenges and social problems. The challenge for the government now is to fully utilise these technologies to improve public services and government administrations. This study focuses on the transformation process of an e-government to become a digital government. The study aims to analyse the current development of e-government in Indonesia and the barriers to implement it as well as to propose how to transform from being an egovernment to becoming a digital government. It uses a qualitative approach supported by secondary data. Focus Group Discussion was held in May 2019 to identify e-government barriers factors. The secondary data, meanwhile, was collected through e-government surveys published by the United Nations and E-government Evaluation issued by Indonesia's Ministry of Empowerment Apparatus and Bureaucracy Reform. Data obtained was analysed using descriptive analysis techniques. Study shows that the development of Indonesia's e-government is slow and lags behind other ASEAN countries. The E-government index in government institutions is not on target. There is a gap between the egovernment indexes and central institutions and gaps between the Provincial and Regency / City Governments. The barriers factors of e-government are: (1) Regulations are not sufficient enough to encourage and guide e-government (2) Lack of data integration; (3) Gaps in the availability of ICT infrastructure between regions; (4) Limited ICT competence and, (5) Bureaucratic culture and leadership.
\end{abstract}

Keywords: Indonesia, e-government, digital transformation, barrier factor, qualitative methodology.

\section{INTRODUCTION}

Industrial Revolution 4.0 and Society 5.0 have encouraged governments to utilise technology to improve public services and government's administration quality. In recent times, the world's Industrial Revolution 4.0 era is massively using the Internet of Things, Big Data, Artificial Intelligence and Robotic technologies for industrial and business sectors. Digital innovation develops rapidly whereby old ways are replaced by new technology. Schwab (2016) stated that the fourth industrial revolution would affect every essence of our human experience. It has disrupted human activities in various fields of life, namely economic, social, political, cultural, and environmental.

In all Industrial sectors, the paradigm shift is marked by new business models such as reshaping production, consumption, transportation, and delivery systems. On the societal front, a paradigm shift is underway in how people work and communicate, express, inform and entertain. Equally, governments and institutions are being reshaped, as are systems of education, healthcare, and transportation, among many others (Schwab, 2016).

In Japan, there has been an "antithesis" of the 4.0 Industrial Revolution called Society 5.0 , which values "the people" more than just data and technology. Society 5.0 is defined as an information society built on Society 4.0 , and the goal is to utilize technology and information for human welfare (Harayama, 2017). The concept of Society 5.0 puts society as a subject that can solve various challenges and social problems by utilising multiple innovations in the era of 
Industrial Revolution 4.0, such as the Internet of Things, Artificial Intelligence, Big Data, and Robotics. Technology, they asserted, can improve the quality of human life (Harayama, 2017).

The impact of the Industrial Revolution 4.0 and Society 5.0 cannot be avoided. Therefore, governments in many countries have developed ICT and digital technology to adapt and take advantage of the opportunity to improve the society's life (Salgues, 2018). Theoretically, the massive technological development has caused the government sectors to improve service performance and governance so that they are more efficient, clean, transparent, accountable, and participatory. Through advanced electronic and mobile services, e-government aims to strengthen the relationship between people and their government; making public services delivery more effective, accessible, and responsive to people's needs; increasing participation in decision-making and making public institutions more transparent and accountable (United Nation, 2016).

The importance of e-government has pushed governments in developing countries to try to perform e-government principles in government services. For example, in 2000, more public services in Malaysia were innovated through the use of electronic means which consist of application, payment, information, communication, procurement, voting, management, and customer service complaints. These new delivery systems will save time and reduce cost as well as mitigate conventional services via counter and telephone so that civil servants can focus more on important tasks (Maizatul, Mohammed Zin \& Wan Idros, 2011).

However, the development of e-government has not occurred equally in all countries. Many developing countries have failed in implementing e-government. The United Nations eGovernment Survey 2016 shows that the number of countries with a low E-Government Development Index (EGDI) value remains at 32 in 2016, out of which 29 are least developed countries (United Nations, 2016). With time, Muñoz and Bolívar (2018) stated that several developing countries began to transform and implemented the e-government system to improve governance and public services.

There are two fundamental reasons digital transformation is needed in government, especially in implementing e-government. First, to make public services and government administration better. The second is to build government readiness for the waves of change caused by the emergence of Industry 4.0 and Society 5.0. Koo (2019) pointed out that it is crucial to establish an innovative strategy for the government that utilises the Internet of Things, Big Data, Artificial Intelligence and Robotic. Notably, to keep up with the changes in the intelligent information society, it is necessary to make a significant transformation from the current e-government towards the digital government.

This study aims to analyse the development of e-government in Indonesia, identify the challenges in implementing e-government, and set up the digital transformation strategy for the Indonesian government.

\section{LITERATURE REVIEW}

The era of digitalization has significantly changed the governance around the world (Saksono, 2020). There are several reasons why the government is transforming and transitioning to become an e-government. The transition to e-government is part of a current trend to reform the public sector, that has emerged in many countries in recent years, spurred primarily by the aspirations of citizens around the world, who are placing new demands on governments. Some requests are adding the need for efficiency, transparency, and overall better performance, and some are trained by the innovation wave that was originated by the adoption of the internet and web-based services. Having witnessed the potential administrative revolution and feeling 
the need to reduce the existent gap between private and public sectors, an increasing number of governments adopted e-government as a strategy to support development (Ronchi, 2019).

E-government can be defined as the use of ICTs to more effectively and efficiently deliver government services to citizens and businesses. It is the application of ICT in government operations, achieving public ends by digital means (UN E-Government Survey in media, 2018). More specifically, Gottschalk (2009) said e-government refers to the delivery of government services (information, interaction and transaction) through the use of information technology, a distinction can be made between the front and back offices of public service delivery organizations. The interaction between citizens and civil servants occurs in the front office, while registration and other activities take place in the back office. Digital Government, e-Government, and e-Governance are terms that have become synonymous with the use of information and communication technologies in government agencies (Gottschalk, 2009). However, Kumorotomo (2009) has stated that e-government is not only about the use of information technology utilised by the government but also how information technology is used for governance transformation.

In a previous study, Muñoz and Bolívar (2018) highlighted the importance of implementing e-government in developing countries. Specifically, e-government can promote civic engagement by enabling the public to interact with government officials and it has the potential to involve citizens in the governance process by engaging them in interaction with policymakers through the policy cycle. Strengthening civic engagement contributes to building public trust in government. It is also associated with high commitment in promoting transparency and accountability, leading to fighting corruption, providing greater access to government information, making government more accountable, reducing crime, and delivering higher quality services to citizens (Muñoz \& Bolívar, 2018).

However, there is a case in Aceh, Indonesia, in which the availability of e-government services provided by some governmental organisations had no positive impact on economic and social improvements to their communities. Instead, it created a form of exclusivity and created an obvious technological gap which eventually saw the government remaining to work on a manual basis. Governance espouses the use of Information and Communication Technology (ICT) systems for every public sector. However, some other public sectors, such as public policy, financial reports, and organisation planning, did not use it. In addition, ICT was not mutually integrated within the organisation (Fazil, 2018).

Ping Gao and Panom Gunawong (2014) pointed out that economic, organisational, and technological factors are responsible for the failure of e-government in developing countries. E-government projects in developing countries entail issues concerning information, technology, and politics (Gao \& Gunawong, 2014). Novita (2014) studied the factors that act as a challenge in implementing e-government in Indonesia: weak leadership, scarce human resources, digital divide, lack of coordination, and inadequate regulation. Furthermore, egovernment in Indonesia faced some limitations, namely (1) The implementation of egovernment is not integrated (2) The use of old technology; It is incompatible with ICT advances in The Industrial Era (3) The application of e-government in public services and government administration is minimal (4) The ICT apparatus competencies are limited (Kementerian Pendayagunaan Aparatur Negara dan Reformasi Birokrasi Republik Indonesia, 2019; Kementerian Komunikasi dan Informatika Republik Indonesia, 2019). Saksono (2016) has stated that the main factor that caused the low implementation of innovation in public services in local government is the inadequate implementation of digitalization in public services. 
Muñoz and Bolívar (2018) explored some limitations of e-government initiatives that have caused the unsuccessful implementation of e-government in developing countries.

1. Strategic E-government Plan, one of the major problems lies when a project is initiated without a strategy, clear objectives and decisions about the use of financial resources, and a clear description of the role of the government. These limitations favour the lack of control mechanism and vision, and coordination between government departments, causing efficiency problems and limiting the participatory process-also, lack of cooperation inside governments and incoordination between departments.

2. Used Technologies Issues. Governments adopted obsolete technology and skipped some stages or even created their paths. Other problems are system incompatibility and problems in using e-government apps, delays in the implementation of new technologies, a decrease in organisational flexibility, and limited and conservative bureaucratic organisational structures.

3. Institutional and Organisational Issues. The organisational and management structures do not favour implanted, appropriate coordination and evolution of e-government initiatives. There are some issues such as rigid organisational and governance structures, incorrect use of ICT, incompatibility of systems, no integration of different organisational structures-interoperability.

4. Technological Issues. Technological incompatibility, complexity, the newness of the technology, lack of ICT technical skills and experience, and security issues are some challenges that can potentially affect e-government development.

5. Leadership and Management Skills - Human Resources. Any resistance to new ICT initiatives should be dispelled by training and incentives to support reform regarding human resources. In this sense, managers should provide an environment where employees are encouraged to use the new technology, making clear the benefits of its use and its impact on their work, trying to reduce resistance among staff to the use of ICT thus combatting any negative attitudes.

6. Policies - Programs. The lack of support from prominent public leaders may be reflected in the lack of appropriate governmental ICT policy formulation to promote the dissemination of information, proper planning for the adoption and diffusion of ICT developmental network infrastructure, and stimulating the improvement of productivity and creativity.

7. Digital Divide - Citizens' Acceptance. Limited access to the internet is primarily due to lack of telecommunications infrastructure, lack of population education, and high illiteracy rates.

8. Legal and Policy Barriers. Finally, the adoption of e-government may encounter legal or policy barriers and privacy and security issues. It is necessary to design applications that integrate privacy protection and minimize the collection and retention of personal information. Also, trust is a vitally important component of e-government projects, so a senior official position responsible for computer security must be designated, and ongoing training to employees on computer security should be provided. Similarly, information must be backed up regularly and the back-ups must be stored in a separate location.

E-government has been recognised worldwide as a strategic option for organisations to enhance their (internal and external) operations. To foster citizen-centric services, they need to integrate themselves and stakeholders both vertically and horizontally. This can be achieved by bringing the efficiencies and experiences of e-business to e-government. That requires new 
e-business models to reduce costs and improve services in the government (Gottschalk, 2009). Several developing countries have transformed the implementation of e-government to be more effective to encourage governance and public services better (Muñoz \& Bolívar, 2018). Innovations are needed in implementing e-government, including regulatory readiness, leadership, innovation culture, and infrastructure (Aminah \& Wardani, 2018).

Digital transformation can be understood from some scholar's viewpoint. Digital transformation can be understood as a strategy for companies to integrate digital and physical elements for changing their business model and set new directions for entire industries (Berman \& Bell, 2011). In the government sectors, digital transformation is defined as the use of technology to improve the performance of government institutions (Westerman et al., 2011). The Austria Municipal Government uses digital transformation as means of modernizing and updating business processes as well as business models supported by Information and Technology, so business processes and business models are at the centre of attention (Peranzo, 2020). It can be concluded that digital transformation in government is a change made by an institution through the development of the internet and digital technology to improve the performance of government agencies. It is important to increase the quality of public services and public administration.

Digital transformation strategies take focus on the transformation of products, processes, and organisational aspects owing to new technologies. Their scope is more broadly designed and explicitly includes digital activities at the interface with or fully on the side of customers, such as digital technologies as part of end-user products (Matt et al., 2015).

Koo (2019) has stated that digital transformation' history has undergone three stages of development as time passes. Stage 1 "Digital Infrastructure Construction (the 1990s)": During this time, the internet was introduced in earnest. The backbone for the internet has begun. Stage 2 "Digital Business Strategy (the 2000s)": During this period, the Internet became popular and was actively used. In addition, infrastructure providers who had the authority and experience in building infrastructure established an information backbone. The government developed many unique functions, such as finance, supply chain, and human resources. It is needed to increase productivity and efficiency through the internet. Stage 3 "Digital Transformation (the 2010s)": This period was when the users' access to the internet has become pervasive and more powerful, and their authority within the internet is strengthened. The mobile revolution and the emergence of social media have helped to share information among users easily (Koo, 2019).

The challenges of digital transformation in the government sector are software integration and upgrades, network interoperability, synchronization in real-time processes and applications, and most importantly, security (Serpanaos, 2018). Inter-organisational information integration has become a key enabler for e-government. Integrating and sharing information across traditional government boundaries involves complex interactions between various participants, all using complicated technical and organisational processes (Gottschalk, 2009). In line with Gottschalk, Schooley and Horan (20017) wrote that inter-organisational systems concepts provide a targeted means to look at the cross-organisational features of a socio-technical system, for example, criminal justice and services to citizens. These examples demonstrate a need to improve sharing of data, information, and experiences across departmental, organisational, geographic, and institutional boundaries. Such interorganisational improvements in information sharing will enhance the performance of public sector services. 
Scholl and Klischewski (2007) listed nine constraints that influence government integration and interoperability. These (1) constitutional and legal constraints, (2) jurisdictional, (3) collaborative, (4) organisational, (5) informational, (6) managerial, (7) cost, (8) technological, and (9) others, should be considered in their full complexity when identifying the optimal stage of interoperability. Concerning e-government integration and interoperability, a total of nine such constraints can be identified from extant literature (Scholl \& Klischewski, 2007).

This study aims to analyse the development of e-government in Indonesia, identify the barriers factors, and to suggest digital transformation strategy to enhance e-government implementation in Indonesia. The analysis of barriers to e-government implementation adapts Muñoz and Bolívar (2018) concept regarding some limitations of e-government. Furthermore, some challenges to realize the e-government transformation by adjusting the idea of digital concept transformation challenges were put forward by Serpanos (2018), Gottschalk (2009), Schooley and Horan (2007), also with Scholl and Klischewski (2007).

\section{RESEARCH METHOD}

A qualitative approach was used in this study. Creswell and Creswell (2018, p. 320) mentioned the characteristic of qualitative research that "qualitative research focuses on the process that is occurring and the product or outcome. Researchers are particularly interested in understanding how things occur".

The methodology of this study can be grouped into two phases. First, research-based phase on three sources: (1) e-government survey published by the UN in 2010-2020, to analyse the evolution of E-Government Development Index (EGDI) which refers to the following elements: Online Service Index (OSI), Telecommunication Infrastructure Index (TII) and Human Capital Index (HCP) and its influence on the composition of EGDI, from the collection of secondary data extracted from the E-government Surveys published by the United Nations (2012-2020). (2) Digital Competitiveness Survey published by IMD World Digital Competitiveness in 2015-2019 consists of 3 elements: knowledge, technology, and futurereadiness. (3) Evaluation of E-government Index published by Ministry of Empowerment of State Apparatus and Bureaucratic Reforms in 2019 (Kementerian Pendayagunaan Aparatur Negara dan Reformasi Birokrasi Republik Indonesia, 2019).

The e-government evaluation aims to measure the index value of central and regional government institutions that represent the e-government maturity level. The evaluation survey used measurement scale as follows: satisfactory category $(4,2-<5,0)$, very good category $(3,5-<4,2)$, good category $(2,6-\leq 3,5)$, moderate category $(1,8-<2,6)$, and, less category $(1-<$ 1,8) (Kementerian Pendayagunaan Aparatur Negara dan Reformasi Birokrasi Republik Indonesia, 2019).

Table 1: Evaluation of E-government Index and Its Component

\begin{tabular}{lcc}
\hline Domain and Aspect of Evaluation & Number of Indicators & Total Score \\
\hline Domain 1 - E-government Internal Policy & $\mathbf{1 7}$ & $\mathbf{1 7 \%}$ \\
Aspect 1: Governance Internal Policy & 7 & $\mathbf{7 \%}$ \\
Aspect 2: Services Internal Policy & 10 & $10 \%$ \\
Domain 2 - Governance of E-government & $\mathbf{7}$ & $\mathbf{2 8 \%}$ \\
Aspect 3: Institution & 2 & $8 \%$ \\
Aspect 4: Planning and Strategy & $\mathbf{2}$ & $\mathbf{8 \%}$ \\
Aspect 5: ITC & 3 & $12 \%$ \\
\hline
\end{tabular}




\begin{tabular}{lcc}
\hline Domain 3 - E-government Services & 11 & $55 \%$ \\
Aspect 6: Government Administration Services Based on & 7 & $35 \%$ \\
Electronics & & $20 \%$ \\
Aspect 7: Public Services Based on Electronics & 4 & 2019 .
\end{tabular}

Source: Kementerian Pendayagunaan Aparatur Negara dan Reformasi Birokrasi Republik Indonesia (2019).

Second, Focus Group Discussion (FGD) was carried out by Research \& Development, Ministry of Home Affairs in May 2019. The objective of the FGD was to understand the factors inhibiting e-government development and formulate a direction for the transformation of egovernment development. FGD participant consists of individuals from the (1) Ministry of Empowerment of State Apparatus and Bureaucratic Reforms (MENPAN), (2) Ministry of Communication and Information (KOMINFO), (3) Ministry of National Development Planning/National Development and Planning Board (Bappenas), (4) Technology Assessment and Application Board, and (5) State Administration Institution.

\section{FINDING AND INTERPRETATION}

\section{Indonesia's E-Government Development}

E-government development in Indonesia has not been maximized. The survey, published every two years, ranks 193 member states of the United Nations (UN).

There are three dimensions of performance measured in EGDI, including the Online Service Index (OSI), the Telecommunication Infrastructure Index (TII), and the Human Capital Index $(\mathrm{HCl})$. Indonesia's e-government has not been ranked low in these indexes. Table 2 shows that Indonesia's EGDI ranking increased from 107 in 2018 to 88 in 2020. However, Indonesia is relatively behind compared to other ASEAN member countries such as Singapore, Malaysia, Brunei, Thailand, the Philippines, and Vietnam. In 2020, except Laos, all ASEAN Countries' egovernment rankings increased significantly. It means that these countries have been maintaining and are continuously working to improve their e-government system (United Nations, 2012, 2014, 2016, 2018, 2020).

Table 2: E-government Development Index and the Indonesian Position Among ASEAN Countries Countries Rankings of 2010-2020

\begin{tabular}{clcccccc}
\hline No & Country & $\mathbf{2 0 1 0}$ & $\mathbf{2 0 1 2}$ & $\mathbf{2 0 1 4}$ & $\mathbf{2 0 1 6}$ & $\mathbf{2 0 1 8}$ & $\mathbf{2 0 2 0}$ \\
\hline 1. & Singapura & 11 & 10 & 10 & 4 & 7 & 11 \\
2. & Malaysia & 32 & 40 & 59 & 60 & 48 & 47 \\
3. & Thailand & 76 & 92 & 54 & 77 & 73 & 57 \\
4. & Brunei & 68 & 54 & 179 & 83 & 59 & 60 \\
5. & Filipina & 78 & 88 & 51 & 71 & 75 & 77 \\
6. & Vietnam & 90 & 83 & 65 & 89 & 88 & 86 \\
7. & Indonesia & 109 & 97 & 110 & 116 & 107 & 88 \\
8. & Kamboja & 140 & 155 & 137 & 158 & 145 & 124 \\
10. & Timor Leste & 162 & 170 & 186 & 160 & 142 & 134 \\
9. & Myanmar & 141 & 160 & 172 & 169 & 157 & 146 \\
11 & Laos & 151 & 153 & 137 & 148 & 162 & 167 \\
\hline
\end{tabular}

Source: Compiled from UN E-government Survey, 2010-2020.

Table 2 shows that in 2014, Indonesia was ranked 110th in the global ranking, and in 2016 , the country experienced its worst performance, dropping to the 116 th position. It has moved up more than ten positions every two years, reaching 107 in 2018 and 88 in 2020. In 2020, when Indonesia's EGDI rank rose to the 88th position, Thailand's EGDI ranking increased 
significantly more than 15 positions. Singapura remains placed in the top rank of EGDI ranking in ASEAN, followed by Malaysia, Thailand, Brunei, and Vietnam.

From Table 3, it can be observed that in 2012-2020 Indonesia's EGDI rankings also fluctuated. In 2012-2016, the indexes of OSITII, and HCI remained under 0,5. Indonesia fared the worst in the TII compared to OSI and $\mathrm{HCl}$. The 2018 and 2020 surveys showed that EGDI rose significantly. OSI, TII, and HCP index performance improved sharply in 2018 and 2020. It caused Indonesia's EGDI ranking to be placed in the 88th position in 2020. Indonesia recorded a fairly good score, a score of 0.6824 for OSI, a score of 0.5669 for TII, and a score of 0.7342 for $\mathrm{HCl}$. The three components are already above the average world score. However, Indonesia is still below the regional average on the telecommunication infrastructure index score or TII when viewed from the Asia Regional and Southeast Asia Sub-Regional groups.

Table 3: EGDI Index, Its Component and Indonesian Position on The World

\begin{tabular}{llccccc}
\hline No & \multicolumn{1}{c}{ Description } & $\mathbf{2 0 1 2}$ & $\mathbf{2 0 1 4}$ & $\mathbf{2 0 1 6}$ & $\mathbf{2 0 1 8}$ & $\mathbf{2 0 2 0}$ \\
\hline 1 & $\begin{array}{l}\text { E-government Development } \\
\text { Index (EGDI) Ranking }\end{array}$ & 97 & 106 & 116 & 107 & 88 \\
2 & $\begin{array}{l}\text { E-government Development } \\
\text { Index (EGDI) }\end{array}$ & 0,4949 & 0,4487 & 0,4478 & 0,5258 & 0,6612 \\
3 & Online Services Index (OSI) & 0,4967 & 0,3622 & 0,3623 & 0,5694 & 0,6824 \\
4 & $\begin{array}{l}\text { Telecomunication Infrastructure } \\
\text { Index (TII) }\end{array}$ & 0,1897 & 0,3054 & 0,3016 & 0,3222 & 0,566 \\
5 & Human Capital Index (HCI) & 0,7982 & 0,6786 & 0,6796 & 0,6857 & 0,734 \\
\hline
\end{tabular}

Sumber: UN E-government Survey, 2012-2020

Digitalization in Indonesia is also lagging behind other ASEAN countries. From the World Digital Competitiveness (WDC) Survey published by IMD WDC in 2018, Indonesia's position is ranked 62 out of 63 countries. It means Indonesia placed the second-lowest from 63 countries. From Table 4, it can be observed that in 2015-2018, Indonesia remained established in the low rankings while Singapore ranked at the top, followed by Malaysia and Thailand. In 2019, Indonesia moved up at 56 ranks. Also, the readiness of innovation to face the digital era, as indicated by the Network Readiness Index, shows that Indonesia is still ranked at 73 of 139 countries.

Table 4: World Digital Competitiveness Index and Indonesian Position among the ASEAN Countries

\begin{tabular}{clccccc}
\hline No & Country & $\mathbf{2 0 1 5}$ & $\mathbf{2 0 1 6}$ & $\mathbf{2 0 1 7}$ & $\mathbf{2 0 1 8}$ & $\mathbf{2 0 1 9}$ \\
\hline 1. & Singapura & 1 & 1 & 1 & 2 & 2 \\
2. & Malaysia & 21 & 24 & 24 & 27 & 26 \\
3. & Thailand & 42 & 39 & 41 & 39 & 40 \\
4. & Philipina & 45 & 46 & 46 & 56 & 55 \\
5. & Indonesia & 60 & 60 & 59 & 62 & 56 \\
\hline
\end{tabular}

Sources: Compiled from IMD WDC Survey 2015-2019

The e-government evaluation of 630 central and regional government institutions published by the Ministry of Administrative Reform and Bureaucratic Reform in 2019 is presented in Figures 1 and 2. Figure 1 and 2 show that the average achievement index of egovernment in three domains (the policy, governance, and service) is 1.98 (moderate category) lowe which is $r$ than the national target of 2.6 (the suitable type). The average achievement index of e-government (governance policy, service policy, planning and strategy, institutional, ICT, government administration, and public services) is below the national target of 2.6 
(Kementerian Pendayagunaan Aparatur Negara dan Reformasi Birokrasi Republik Indonesia, 2019).

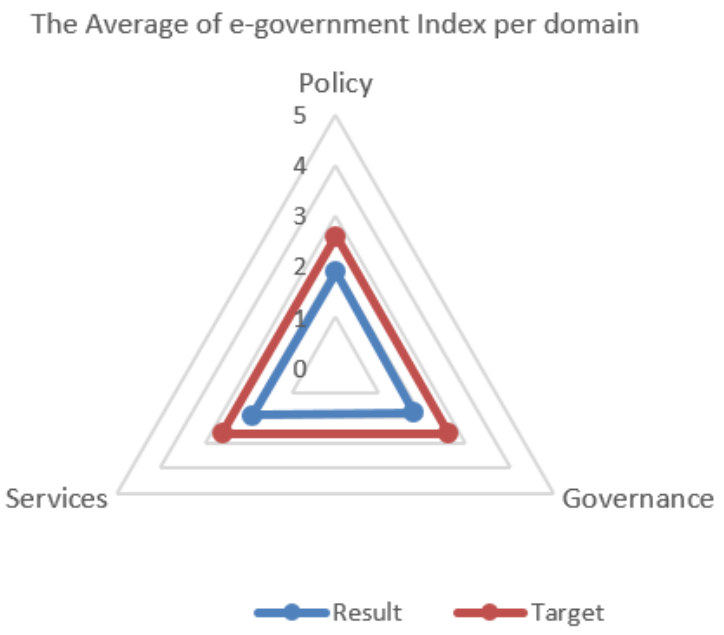

Figure 1: The Average e-Government Index in 3 Domain (Source: Kementerian Pendayagunaan Aparatur Negara dan Reformasi Birokrasi Republik Indonesia, 2019)

The Average e-Government Index Per Aspect
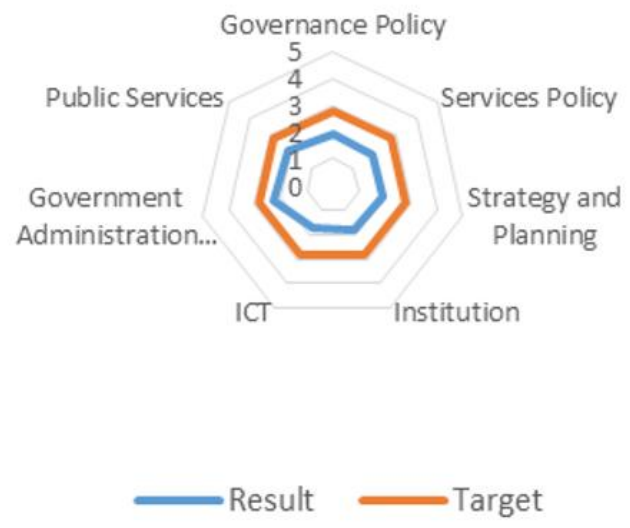

Figure 2: The Average e-Government Index in 7 aspect (Source: Kementerian Pendayagunaan Aparatur Negara dan Reformasi Birokrasi Republik Indonesia, 2019)

In Figure 3, it can be observed that there are gaps in the e-government development index between central government institutions. For example, the average index of 34 ministries is $74 \%$, or above the national target (2.88) which demonstrated that the egovernment system can be placed in the excellent category $(2.6-\leq 3.5)$. On the other hand, only $29 \%$ of state institutions (People's Consultative Assembly, House of Representatives, Regional House of Representatives, Presidential Institution, Constitutional Court, Judicial Commission, and Finance Audit Board) have reached the target. In comparison, the remaining $71 \%$ of state institutions have not reached the e-government index target. The gap also occurs 
in local government. The average index of 34 province governments reached $9 \%$ above the target while the district government (370) was just only $8 \%$ above the target. Meanwhile the city government reached $25 \%$ above the target (Kementerian Pendayagunaan Aparatur Negara Republik Indonesia, 2019).

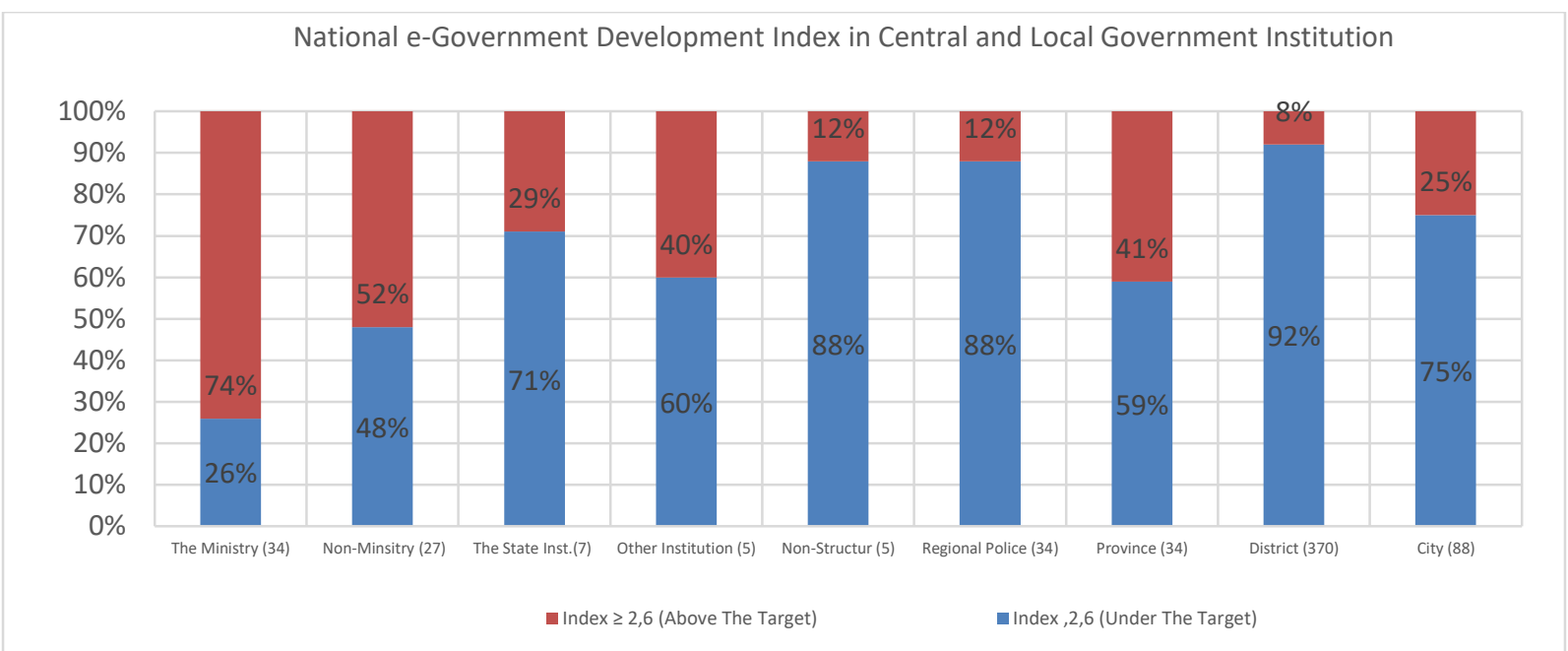

Figure 3: National e-Government Index Central and Local Government

(Source: Kementerian Pendayagunaan Aparatur Negara dan Reformasi Birokrasi Republik Indonesia, 2019)

Table 5 showed that Indonesia was trailing behind other ASEAN countries in competitiveness index, ease of doing business index, the effectiveness of government index, and the ability to control corruption.

Table 5: The Competitiveness Index, Easy Doing Business Index, Corruption Perception Index and Government Index, and Indonesian Position among The ASEAN Countries

\begin{tabular}{|c|c|c|c|c|c|c|c|c|}
\hline \multirow[t]{2}{*}{ Negara } & \multicolumn{2}{|c|}{$\begin{array}{c}\text { Global } \\
\text { Competitiveness } \\
\text { Index (2019) }\end{array}$} & \multicolumn{2}{|c|}{$\begin{array}{c}\text { Ease of Doing } \\
\text { Business (2020) }\end{array}$} & \multicolumn{2}{|c|}{$\begin{array}{c}\text { Corruption } \\
\text { Perception Index } \\
2019 \text { (180 Countries) }\end{array}$} & \multicolumn{2}{|c|}{$\begin{array}{c}\text { Government } \\
\text { Effectiveness Index } \\
2017\end{array}$} \\
\hline & Rank & Score & Rank & Score & Rank & Score & Rank & Score \\
\hline Singapore & 1 & 84,8 & 2 & 86,2 & 4 & 85 & 1 & 100 \\
\hline Malaysia & 27 & 74,6 & 12 & 81,5 & 51 & 53 & 51 & 76,44 \\
\hline Thailand & 40 & 68,1 & 21 & 80,1 & 101 & 36 & 71 & 66,83 \\
\hline Indonesia & 50 & 64,6 & 73 & 69,6 & 85 & 40 & 98 & 54,81 \\
\hline Brunei & 58 & 62,8 & 66 & 70,1 & 35 & 60 & - & 84,13 \\
\hline Vietnam & 67 & 61,5 & 70 & 69,8 & 96 & 37 & 99 & 52,88 \\
\hline Philipina & 64 & 61,9 & 95 & 62,8 & 113 & 34 & 101 & 51,92 \\
\hline
\end{tabular}

Source: Compiled from World Economic Forum, World Bank, Transparency International

\section{The Barriers Factors of e-Government Implementation}

The poor performance in the e-government index indicates that there are challenges and barriers which must be overcome. Based on the results of the Focus Group Discussion with participants comprising (1) Ministry of Empowerment of State Apparatus and Bureaucratic Reforms (MENPAN), (2) Ministry of Communication and Information (KOMINFO), (3) Ministry of National Development Planning/National Development and Planning Board (Bappenas), (4) Technology Assessment and Application Board and (5) State Administration Institution, it was found that the challenges faced in implementing e-government system is the slow response in facing dynamic ICT changes, digital divide and lack of data integration. 
First, e-government policies are considered too slow in responding to the dynamics of ICT development and the community's needs for digital services. According to Indonesia's Ministry of Communication and Information (2019) $64 \%$ of Indonesians used the internet. The number of cellphone connections was 338.2 million or $124 \%$ of the population. In addition, there are 160 million social media users with a penetration rate of $59 \%$. This condition has implications for (1) an increasing number of users of online services, (2) an increase in online transactions, (3) people working in online-based industries have increased significantly (4) interconnection of services among businesses. Ironically, until 2018, there were no egovernment regulations and policies available to regulate the dynamic digital changes (Kementerian Komunikasi dan Informatika Republik Indonesia, 2019).

Second, lack of data integration in e-government implementation also hampers further development and implementation of e-government. In particular, Government institutions have made multiple budget applications that have caused budget duplication. Based on the National ICT Council Survey (2018), there is a duplicate budget request by $65 \%$ of Indonesia's government institutions to buy similar applications which are not needed. In addition, data integration between institutions is low, which causes low data validity and exchange. Also, although there are 2700 Data Centres in 630 central and regional government institutions, most of these data centres do not fulfil the criterias set by international standards.

The competency of employees who are well versed in ICT is minimal. Based on the results of the $\mathrm{MoCl}$ survey (2018), the majority of employees in government institutions are competent in basic skills such as word processing and how to use the web. However, digitalbased public services require several specialised skills like programming, application development analysis and software applications, in which the government employees lack.

Most ministries and government institutions do not do not have a culture of working electronically, are egoistic and lack collaborative efforts. Correspondingly, the implementation of e-government is not well received because most officials fear losing their positions and cannot see themselves leading in a digitalised environment.

\section{Digital Transformation of e-Government}

The analysis shows that the development of e-government and digital government in Indonesia has not met the predetermined target that will supposedly encourage the creation of better public services and governance. It can be seen from various indexes which puts Indonesia at a low level of global competitiveness and accessibility in doing business, low government effectiveness, and high levels of corruption.

A new strategy is needed to improve e-government implementation in Indonesia, namely digital transformation in e-government. There are six aspects to change, explicitly (1) regulations and policy, (2) digital system, (3) bureaucratic governance, (4) human resource, culture and leadership, and (5) ICT Infrastructure (Table 6). 
Table 6: Digital Transformation of E-government

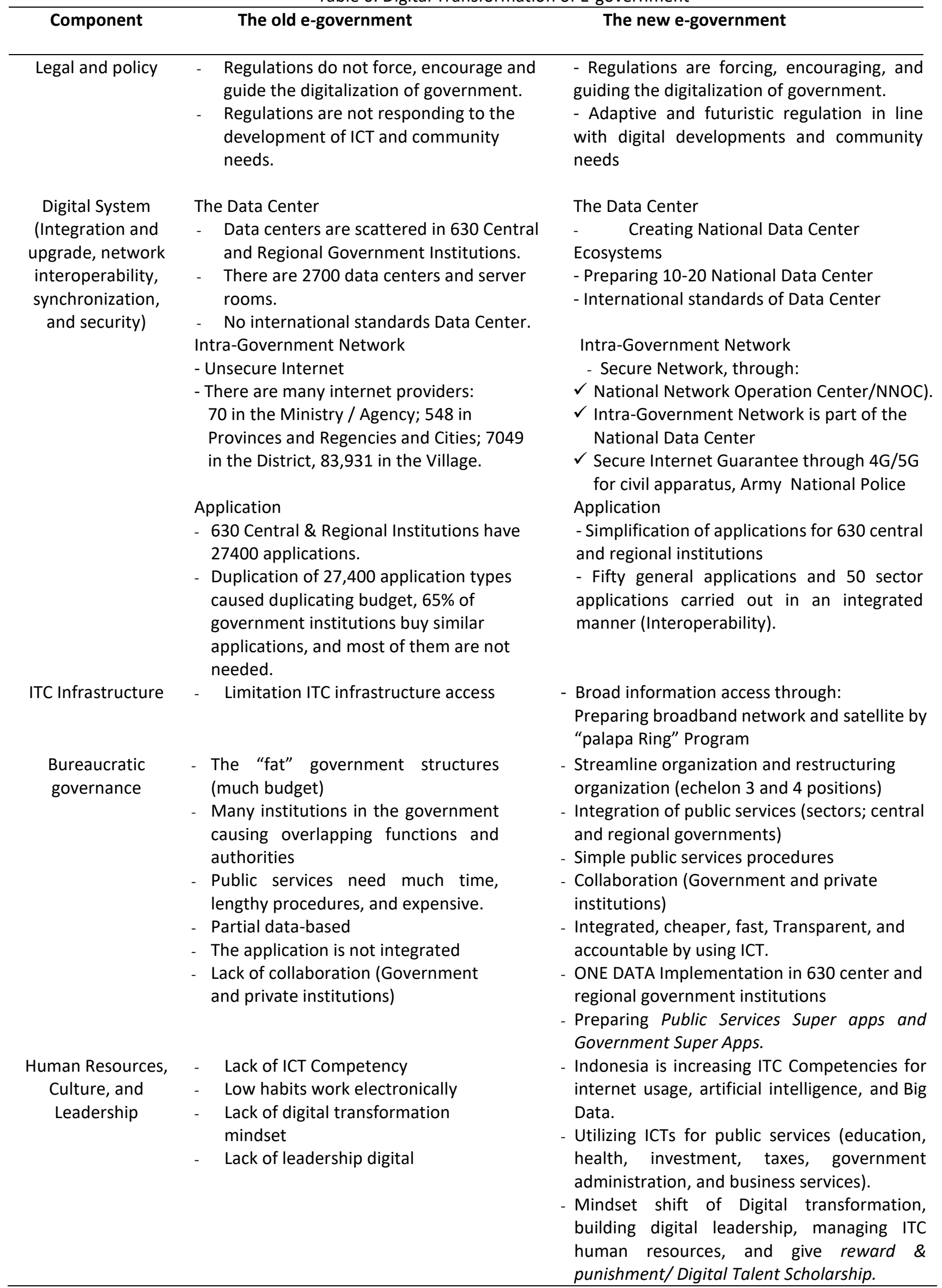

Source: FGD (summarized by the author) 


\section{DISCUSSION}

Indonesia's e-government development has not been maximized. The implementation of egovernment in central and local government institutions has not reached the predetermined target. Indonesia's performance in the E-government Development Index (EGDI) tends to fall behind the other ASEAN countries. This condition reflected how Indonesia's e-government system is lagging compared to the other ASEAN countries, especially in terms of competitiveness index, ease of doing business index, the effectiveness of government index, and the ability to control corruption.

The barriers to implement e-government in Indonesia can be identified as follows: weak leadership, scarce human resources, digital divide, lack of coordination, and inadequate regulation. This is similar to Kumorotomo's (2009) findings which stated that the main problems of e-government implementation in Indonesia are infrastructure, leadership, and cultural factors.

First, the lack of availability of ICT infrastructure. The development of e-Government in government institutions requires the availability of infrastructure such as satellite technology, electricity networks, internet networks and the availability of computers.

The second problem is the leadership factor. This factor is influenced by the existence of a mismatch between the central government policies and the local government's policies, inadequate regulations, inadequate budget allocations and unclear standardization of systems, all of which are determined by the commitment of the leaders or officials for the implementation of e-government. There is a lot of evidence to show that the success of using e-government in the regions is primarily determined by the commitment of the Governor, Regent, or Mayor in the local area concerned.

The third is cultural factors. Local governments in Indonesia have easy access to technology, and many leaders have a vision of developing electronic services. However, the problem is e-government often collides with working cultural factors that are not supportive. This working cultural factor among bureaucrats in government institutions often results in a lack of awareness and appreciation of the importance of e-government. What often arises is the excessive fear or concern that the e-government application will threaten an official's existing position. Integration between state agencies, departmental and non-departmental agencies is always constrained because they do not want to share data and information.

\section{CONCLUSION AND RECOMMENDATION}

There are some barriers factors concerning e-government implementation in Indonesia. Explicitly, e-government regulations and policies are considered slow to respond to the dynamics of ICT development and the community's needs for digital services. The other crucial problems in e-government implementation are low data integration; application of egovernment in public services and government administration are minimal; the use of old technology is incompatible with ICT advances in The Industrial era; the low ICT competency of apparatus; cultural mindset and silos in government institutions; lack of collaboration among stakeholders, lack of digital leadership vision, and gaps availability of ICT infrastructure, especially in the remote area.

Therefore, digital transformations in the performance of e-government in Indonesia are needed, which include the following elements: organising legal and policies which can guide egovernment implementation; improving the digital system, namely of the data centre, intragovernment network and applications more integrated and straightforward; bureaucratic 
restructuring; improve bureaucracy ICT competences; changing work culture that encourages apparatus to work in digital ways; developing leadership who has a digital vision, enhancing sector collaboration and growing collaboration between governments and the private sector and provision of ICT infrastructure, especially equitable internet access to remote areas.

This study recommends strategies for accelerating digital transformation in egovernment implementation. First, strengthe e-government-based governance systems; (1) strengthen policies by compiling risk management guidelines, service management guidelines, and ICT audit management guidelines. (2) Effective collaboration of the e-government by a coordination team that involves related institutions (3) To make effective use of the architecture and map of the e-government plan. The second is to accelerate the integration of e-government services to stop government agencies from building their applications and encourage shared applications. It is to prevent silos in central and regional government agencies.

The third is preparing digital infrastructure technology, specifically by building a shared e-government infrastructure, utilising broadband networks for accessibility, utilising cloudbased applications, developing technology-based services 4.0 (cloud computing, artificial intelligence, big data, and the internet of things).

Lastly, our suggestion is to develop the apparatus' ICT competence, inculcating digital work culture in government organizations and developing partnerships both in government organizations and the other institutions that have adequate ICT capacity.

\section{BIODATA}

Sitti Aminah is a researcher in the field of Politics and Government, an expert in the Research and Development Agency (BPP) of the Ministry of Home Affairs. She has been conducting mentoring for the Indonesia-Australia Training Project (IASTP 2004-2007) in the field of Capacity Building for Regional Apparatus, Training and Assessment, and Public Accountability in North Maluku Province. She is also a Master of Trainer for Training on Capacity Building for Village Government Apparatus 2015-2017 in the Ministry of Home Affairs. Email: sittiaminah.kemendagri@gmail.com

Herie Saksono is a senior researcher in Business and Management at the Ministry of Home Affairs of the Republic Indonesia. He gained teaching experience when he was a lecturer at the Institute for Governmental Studies (IPDN) on Jakarta Campus in 2012-2013. He was a lecturer for the post-graduate program in Masters in Public Administration (MAP) at Muhammadiyah University of Palangka Raya in 2014-2015. He carries out various collaborative research activities with partner ministries/agencies, local government, village administration, research and development, creative communities, donor agencies and universities. Email: herie.saksono26@gmail.com 


\section{REFERENCES}

Aminah, S., \& Wardani, D. K. (2018). Readiness Analysis of Regional Innovation Implementation. Jurnal Bina Praja, 10(1), 13-26. https://doi.org/gdaf

Berman, S., \& Bell, R. (2011). Digital transformation: Creating new business models where digital meets physical. In IBM Institute for Business Value (Ed.), IBM global business services: Strategy and transformation [Executive report]. IBM Global Business Services. https://www.ibm.com/downloads/cas/KWRV8QK6

Creswell, J. W., \& Creswell, J. D. (2018). Mixed methods procedures. In, Research design: Qualitative, quantitative, and mixed methods approaches (Chap. 10, 5th ed.). SAGE.

Fazil, M. (2018). Characteristic of information and communication technology (ICT) innovation and its application (A descriptive study in Lhokseumawe City). Jurnal Komunikasi: Malaysian Journal of Communication, 34(3), 379-391. https://doi.org/gdai

Gao, P., \& Gunawong, P. (2014). Understanding e-Government failure from an actor-network perspective: The demise of the Thai smart ID card. IGovernment Working Paper Series (February 2016), paper no. 23, 1-27. Centre for Development Informatics.

Gottschalk, P. (2009). Maturity levels for interoperability in digital government. Government Information Quarterly, 26(1), 75-81. https://doi.org/10.1016/i.giq.2008.03.003

Harayama, Y. (2017). Society 5.0: Aiming for a new human-centered society - Japan's science and technology policies for addressing global social challenges. Cover Story Collaborative Creation through Global R\&D TRENDS in Hitachi Review, 66(6), 553-559.

Kementerian Komunikasi dan Informatika Republik Indonesia. (2019). Laporan tahunan 2019 Kementrian Komunikasi dan Informatika Republik Indonesia. KOMINFO Indonesia. https://www.kominfo.go.id/content/all/laporan tahunan

Kementerian Pendayagunaan Aparatur Negara Republik Indonesia. (2019). Kebijakan dan evaluasi sistem pemerintahan berbasis elektronik (Presentation material was delivered at a Focus Group Discussion, at the Research and Development Agency, Ministry of Home Affairs 8, May 2019).

Kementerian Pendayagunaan Aparatur Negara dan Reformasi Birokrasi Republik Indonesia. (2019). Sistem pemerintahan berbasis elektronik (SPBE). https://kita.menpan.go.id/wp-content/uploads/2019/11/Paparan-SPBE-SistemPemerintahan-Berbasis-Elektronik.pdf

Koo, E. (2019). Digital transformation of Government: from E-Government to intelligent EGovernment [Master thesis]. Massachusetts Institute of Technology.

Kumorotomo, W. (2009). Kegagalan penerapan e-government dan kegiatan tidak produktif dengan Internet. https://kumoro.staff.ugm.ac.id/2009/egov.pdf

Matt, C., Hess, T., \& Benlian, A. (2015). Digital transformation strategies. Bus Inf Syst Eng, 57, 339-343 (2015). https://doi.org/10.1007/s12599-015-0401-5

Maizatul Haizan Mahbob, Mohammed Zin Nordin, \& Wan Idros Wan Sulaiman. (2011). Inovasi perkhidmatan awam Malaysia melalui pelaksanaan e-kerajaan: Satu kajian empirik tentang penerimaan e-servis di Lembah Kelang. Jurnal Komunikasi: Malaysian Journal of Communication, 27(1), 18-33.

Muñoz, L. A., \& Bolívar, M. P. R. (2018). Experiences of e-government development implementation in developing countries: Challenges and solutions. In, International egovernment development: Policy, implementation and best practice (pp. 3-18). Springer. 
Novita, D. (2014). Faktor-faktor penghambat pengembangan e-government: Studi kasus pemerintah Kota Palembang, Sumatera Selatan. Jurnal Eksplora Informatika, 4(1), 4352.

Peranzo, P. (2020, March 4). What is digital transformation \& why it's important for businesses. imaginovation.net [blog]. https://www.imaginovation.net/blog/what-is-digital/

Ronchi A. M. (2019). e-Government: Background, today's implementation and future trends. In, e-Democracy: Toward a new model of (inter)active society (Chap. 5, pp. 93-196). Springer. https://doi.org/10.1007/978-3-030-01596-1 5

Saksono, H. (2016). Wajah baru otonomi daerah: Status kinerja versus kondisi realistis di wilayah provinsi Kalimantan Selatan. Jurnal Kebijakan Pembangunan, 11, 63-75.

Saksono, H. (2020). Innovation hub: Media kolaborasi menuju pemerintahan daerah inovatif. Nahkoda: Jurnal Ilmu Pemerintahan, 19(1), 1-16. https://doi.org/gdan

Salgues, B. (2018). Society 5.0: Industry of the future, technologies, methods and tools (Vol. 1). Wiley.

Scholl, H. J., \& Klischewski, R. (2007). E-government integration and interoperability: Framing the research agenda. International Journal of Public Administration, 30(8-9), 889-920. https://doi.org/10.1080/01900690701402668

Schooley, B. L., \& Horan, T. A. (2007). Towards end-to-end government performance management: Case study of interorganizational information integration in emergency medical services (EMS). Government Information Quarterly, 24(4), 755-784. https://doi.org/10.1016/i.giq.2007.04.001

Schwab, K. (2016, January 14). The fourth industrial revolution: What it means, how to respond. World Economic Forum.

Serpanas, D. (2018). The cyber-physical systems revolution? Computer, 51, 70-73. https://doi.ieeecomputersociety.org/10.1109/MC.2018.1731058

United Nations. (2012). E-government survey 2012: E-government for the people. United Nations Department of Economic and Social Affairs. Public Administration UN. https://publicadministration.un.org/en/Research/UN-e-Government-Surveys

United Nations. (2014). E-government survey 2014: E-government for the future we want. United Nations Department of Economic and Social Affairs. Public Administration UN. https://publicadministration.un.org/en/Research/UN-e-Government-Surveys

United Nations. (2016). UN e-government survey 2016: E-Government in support of sustainable development. United Nations Department of Economic and Social Affairs. Public Administration UN. https://publicadministration.un.org/egovkb/enus/reports/un-e-government-survey-2016

United Nations. (2018). E-government survey 2018: gearing e-government to supports transformation towards sustainable and resilient societies. united nations department of economic and social affairs. Public Administration UN. https://publicadministration.un.org/egovkb/en-us/Reports/UN-E-GovernmentSurvey-2018

United Nations. (2020). E-government survey 2020: Digital government in the decade of action for sustainable development, with addendum on Covid-19 response. United Nations Department of Economic and Social Affairs. Public Administration UN. https://publicadministration.un.org/egovkb/en-us/Reports/UN-E-GovernmentSurvey-2020

United Nations. (2018). E-government survey in media. Public Administration UN. https://publicadministration.un.org/egovkb/en-us/about/unegovdd-framework 
Westerman, G., Calméjane, C., Bonnet, D., Calméjane, C., Ferraris, P., \& Andrew McAfee. (2011, Nov 17). Digital transformation: A road-map for billion-dollar organizations. Capgemini. https://www.capgemini.com/it-it/resources/digital-transformation-a-road-map-forbillion-dollar-organizations/

World Economic Forum. (2018). The global competitiveness report 2018. https://www.weforum.org/reports/the-global-competitveness-report-2018 